\title{
Experimental \& Statistical Parametric Investigation of CWML Sandwich Panel
}

\author{
Tushar Kavatkar \\ Assistant Professor, Department of mechanical Engineering, \\ Finolex Academy of Management \& Technology, \\ Ratnagiri, 415639 \\ University Of Mumbai, Mumbai \\ Suresh Jangale, Pushpak Joshi, Niraj Kadam, Akhilesh Vinchu \\ UG Students, Department of mechanical Engineering, \\ Finolex Academy of Management \& Technology, \\ Ratnagiri, 415639 \\ University Of Mumbai, Mumbai
}

\begin{abstract}
Corrugated Wire Mesh Laminates (CWML) is open cell type cellular structures manufactured by bonding several layers of metallic corrugated wire meshes on top of each other. Due to their open cell structure and the mechanical properties of the parent material, CWML can offer high stiffness and strength per unit weight. The main loading in such applications is transverse compression. The sandwich Panels are fabricated according to the array obtained from Taguchi's methodology. This work investigates and characterises the behaviour of corrugated wire mesh laminates sandwich panel prepared from perforated sheets under transverse compression loading. The parameters considered during design of experiments are Types of wire mesh, materials of wire mesh and number of corrugated layers. Experimental testing is conducted on several samples of two layer and three layer wire mesh laminate sandwich panels under transverse compression. To find the optimum combination, strength to weight ratio is considered. Design of CWML with optimum levels of control factors results in maximum strength as well as light weight structure.
\end{abstract}

Keywords: Corrugated Wire Mesh Laminates, Sandwich Panel, Taguchi's Methodology, Strength to Weight Ratio.

\section{INTRODUCTION}

Corrugated Wire Mesh Laminates (CWML) are relatively a new class of synthetic open celled cellular structures that have potential for applications in fields such as biomedical, aerospace, mechanical and automotive engineering [4]. Cellular structures cover a wide range of both natural and man-made structural materials such as foam, sponge, wood, cork, bone, honeycomb, micro truss structures, lattice cell structures, and so on [10]. One of the advantages of cellular structures is that they can have a relatively high fraction of open space, hence a much lower density as compared to the parent material starting with commercially available perforated sheet as the raw material. CWML is fabricated by bonding together several layers of the perforated sheet after they are put through a die and punch arrangement to create corrugations in them. The corrugations provide the layers with high rigidity and stiffness in the direction perpendicular to the corrugations. Typically, alternate layers of the CWML are arranged orthogonally so that the high stiffness provided by the corrugation is available in both directions. Unlike metallic foam, which also has potential for similar application, the CWML offers the advantage of controllable rigidity and strength [1]. The material of the perforated sheet, types of perforated sheets, material of sheet, and corrugation parameters such as the corrugation height and the base angle can be altered to provide a wide range of strength to the laminate structure [3]. In aerospace and mechanical engineering fields CWML has potential for applications as high strength, low weight, core material in structural sandwich construction [4]. Similarly in the orthopaedic implants load carrying capacity of the CWML are properties of main interest. In order to find maximum strength of CWML under compressive loading number of experiments can be performed for different combinations of operating parameters and their optimum values can be found out. Sandwich panels offer a wide range of advantages over conventional monolithic materials and their use is continuously increasing in applications in the aerospace, automotive, naval and construction industries [5]. The distinctive feature of CWML is its ability to impart excellent ventilation characteristics, avoiding problems associated with humidity retention that is common in cellular core materials (e.g. polymeric foams and honeycombs) [5]. 
By applying design of experimentation (DOE) approach the number of experiments required can be reduced without affecting the results. Taguchi's concept of orthogonal array is used to find optimize solution. Taguchi's simple, effective and systematic approach helps to find optimal CWML parameters which is not only a reliable tool to find optimize solution but also helps to reduce experimental efforts. The following paper outlines the parametric experimentation of CWML sandwich panels.

\section{DESIGN AND DEVELOPMENT}

Work is undertaken into selection of parameters, fabrication of CWML, experimental testing using Taguchi's design of experiments. If the numbers of parameters considered are more as in the case of many practical examples, a full factorial design results in a large number of experiments. Taguchi methodology can be used to reduce this large number of experiments to a practical level [16]. Taguchi analysis provides guidelines for factorial experiments to improve its accuracy. It investigates how different parameters affect the mean and variance of a process performance characteristic that defines how well the process is functioning [13].

\subsection{ESTABLISHMENT OF OBJECTIVE FUNCTION}

The objective of the present work is to determine the optimum levels of the parameters configuring CWML sandwich panel that result in the maximum strength of CWML sandwich panel along with light weight.

\subsection{DETERMINATION OF CONTROLLABLE FACTORS}

Control factors are those which can be easily controlled while the noise factors are usually uncontrollable, which always cannot be eliminated, and which cause variations in the output. In the present study selected signal factors are: material of wire mesh, type of wire mesh and number of corrugated layers while noise factors are surrounding temperature, moisture content in air, acidic environment etc. In the study, square and round perforated sheets were chosen for fabrication of the CWML due to the fact this is a simple form. The wire mesh used is perforated sheets made of 6061 aluminum and 304 Stainless steel. Al is commonly used as core material for lightweight sandwich constructions and SS is used for corrosion resistance. From the point of view of increasing mechanical strength and stiffness, it may be desirable to have multiple layers of wire mesh with multiple corrugations in each layer. Hence the levels of no of corrugated layers are selected as 2 and 3.

Table - 2.1 Control factors with their levels

\begin{tabular}{|c|c|c|}
\hline Levels & 1 & 2 \\
\hline \multicolumn{2}{|c|}{ Control factors } \\
\hline Types of Wire Mesh & Round perforated & Square perforated \\
\hline Material & Aluminum & Stainless steel \\
\hline Number of Corrugated Layers & 2 & 3 \\
\hline
\end{tabular}

\subsection{SELECTION OF ORTHOGONAL ARRAY}

The orthogonal array is arrays in which columns are mutually orthogonal i.e. for any pair of column, all combinations of factor level occur, and they occur for equal number of times. In simple words in orthogonal array, equal chance is given to the every level of every parameter [16]. The Taguchi orthogonal array layout gives the way to perform minimum number of experiments which are sufficient to give the full information of all the factors that affect the desired response [13]. There are many standard orthogonal arrays available, with the combinations of number of controllable factors and number of their levels. L8 orthogonal array is selected for the present investigation in which eight experiments need to be performing with three parameters having two levels each. The selected orthogonal array along with the details of levels of each parameter is shown in Table 2.2. 
Table -2.2 orthogonal arrays

\begin{tabular}{|c|c|c|c|c|c|c|}
\hline $\begin{array}{c}\text { Ex. } \\
\text { No }\end{array}$ & A & B & C & $\begin{array}{c}\text { Type Of } \\
\text { Wire Mesh }\end{array}$ & $\begin{array}{c}\text { Material Of } \\
\text { Wire Mesh }\end{array}$ & $\begin{array}{c}\text { No of } \\
\text { Layers }\end{array}$ \\
\hline 1 & 1 & 1 & 1 & Round & AL & 2 \\
\hline 2 & 1 & 1 & 2 & Round & AL & 3 \\
\hline 3 & 1 & 2 & 1 & Round & SS & 2 \\
\hline 4 & 1 & 2 & 2 & Round & SS & 3 \\
\hline 5 & 2 & 1 & 1 & Square & $\mathrm{AL}$ & 2 \\
\hline 6 & 2 & 1 & 2 & Square & $\mathrm{AL}$ & 3 \\
\hline 7 & 2 & 2 & 1 & Square & SS & 2 \\
\hline 8 & 2 & 2 & 2 & Square & SS & 3 \\
\hline
\end{tabular}

\subsection{CORRUGATION PROCESS}

Die and punching process is used to make corrugations in the wire mesh. The die and punch designed and manufactured under this work is shown in Figure 2.1 and Figure 2.2. The pair of die and punch was designed \& manufactured with corrugation angle $55^{\circ}$. The length $\mathrm{Lx}$ and width Ly (area) of the corrugated wire mesh is $\left(10 \times_{100}\right) \mathrm{mm} 2$. Also the base length LB is $(20 \mathrm{~mm})$. The corrugation height $\mathrm{Hc}$ is $14.28 \mathrm{~mm}$. The plain wire mesh is fed through this pair of die and punches to create corrugations in them. Figure 2.3 show samples of corrugated wire mesh created by the above process.

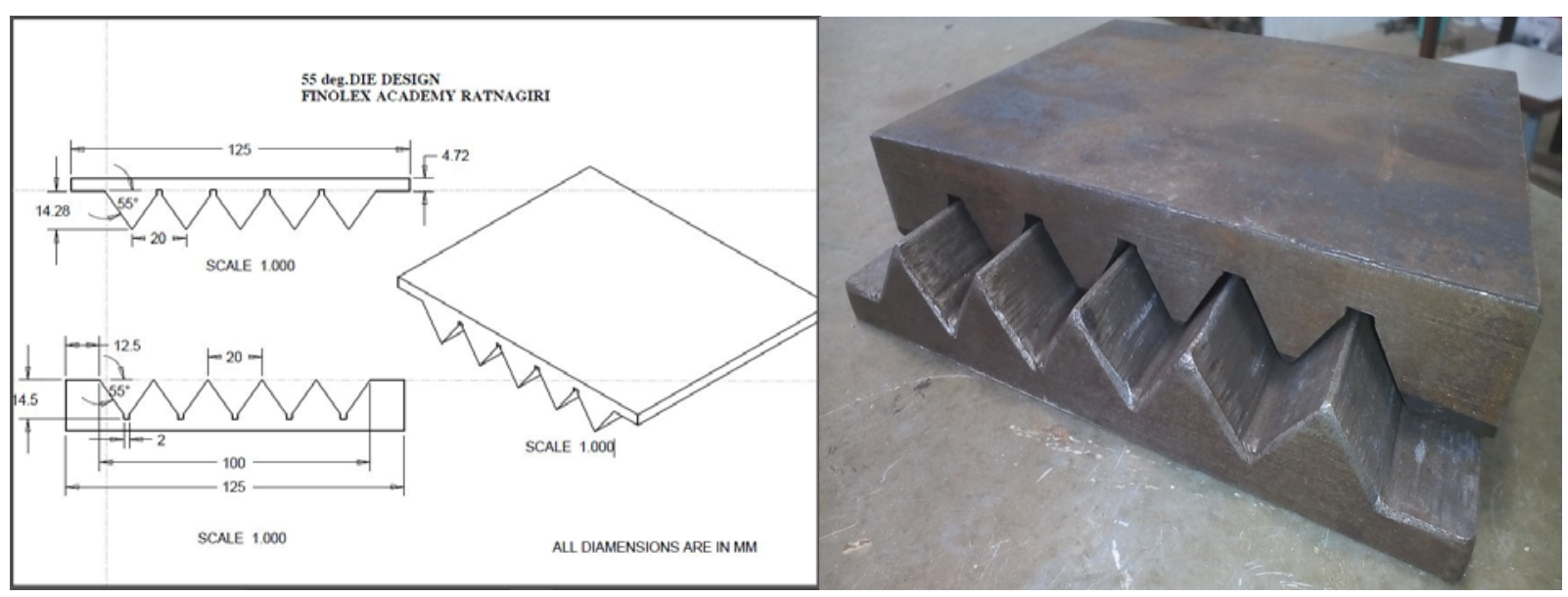

Figure 2.1 Design of Die used for corrugation

Figure 2.2 Manufactured die with corrugation angle of $55^{\circ}$ 


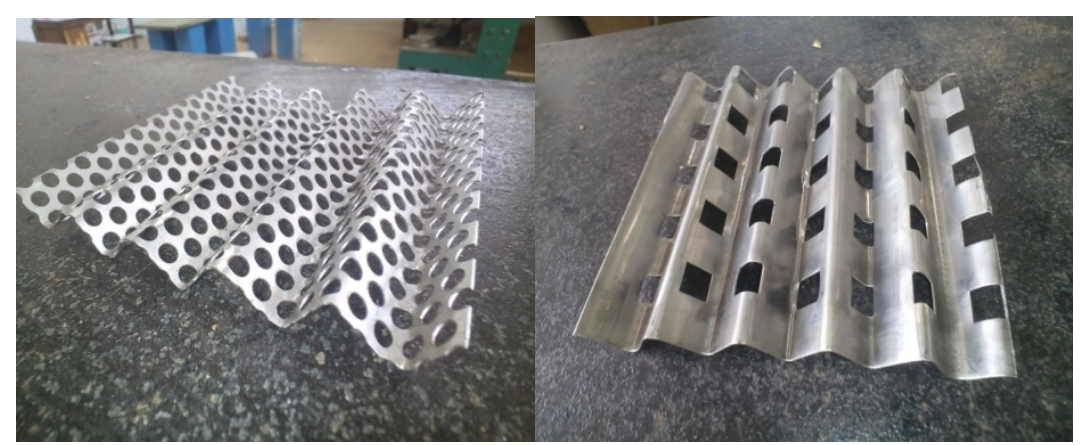

Figure 2.3 Corrugated Perforated sheets

\subsection{BONDING TECHNIQUE}

The bonding technique used in the present work is adhesive bonding with epoxy resin. Epoxy adhesives are two part (resin and hardener) adhesives having large variations in its viscosities. Epoxy adhesives forms tough, rigid thermo set polymers with high strength and good environmental resistance [18].

\subsection{LAMINATION}

Then samples for laminations were prepared by applying bonding material (araldite) to the corrugated wire mesh and then assembling the layers over each other one by one according to the laminate structure. All specimens were cured at room temperature for 15 hours. Some samples of CWML fabricated using the present technique are shown in figure 2.4 .

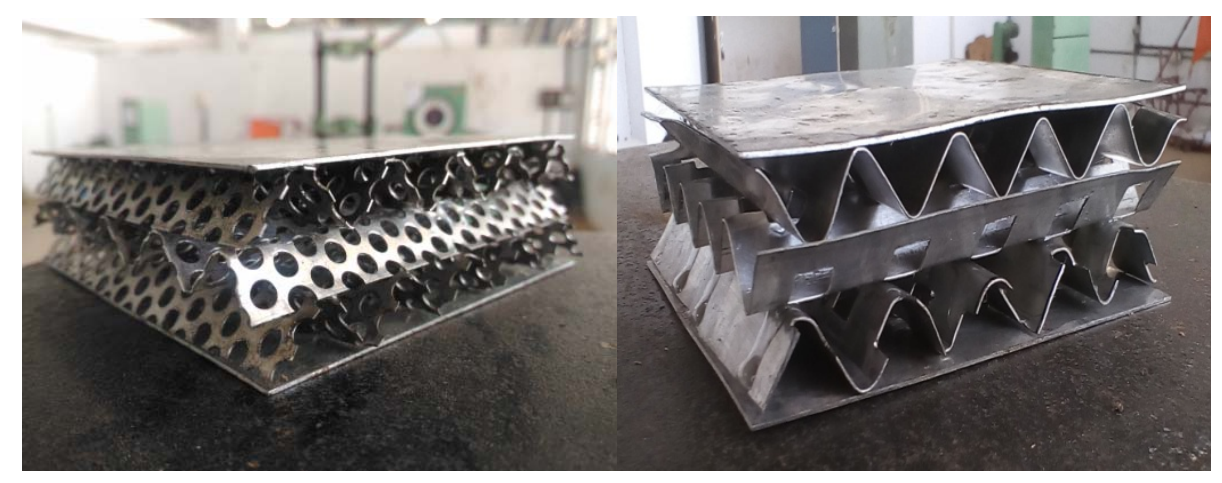

Figure 2.4 Samples of CWML Sandwich Panels

\subsection{EXPERIMENTAL TESTING}

Compression test of each specimen of corrugated wire mesh laminates was conducted at room temperature using universal testing machine (INSTRON) manufactured by Fine spavy associates and engineers pvt.ltd having $60 \mathrm{KN}$ maximum load as shown in Figure 2.5.

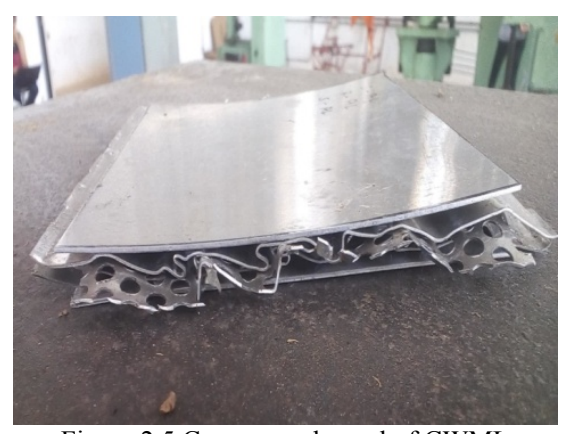

Figure 2.5 Compressed panel of CWML 
Table - 3.1 Experimental Results

\begin{tabular}{|c|c|c|c|c|c|c|}
\hline $\begin{array}{c}\text { Expt. } \\
\text { No }\end{array}$ & Material & Orientation & $\begin{array}{c}\text { No of } \\
\text { layers }\end{array}$ & $\begin{array}{c}\text { Compressive } \\
\text { Load } \\
\mathrm{kN}\end{array}$ & $\begin{array}{c}\text { Bonded } \\
\text { Weight } \\
\mathrm{Kg}\end{array}$ & $\begin{array}{c}\text { Strength/Weight } \\
\text { Ratio } \\
\mathrm{kN} / \mathrm{kg}\end{array}$ \\
\hline 1 & $\mathrm{Al}$ & Round & 2 & 12.6 & 0.058 & 217.24 \\
\hline 2 & $\mathrm{Al}$ & Round & 3 & 15.3 & 0.068 & 225.0 \\
\hline 3 & $\mathrm{Al}$ & Square & 2 & 15.0 & 0.071 & 211.26 \\
\hline 4 & $\mathrm{Al}$ & Square & 3 & 16.5 & 0.087 & 189.65 \\
\hline 5 & $\mathrm{SS}$ & Round & 2 & 24.1 & 0.099 & 243.43 \\
\hline 6 & $\mathrm{SS}$ & Round & 3 & 31.1 & 0.132 & 235.60 \\
\hline 7 & $\mathrm{SS}$ & Square & 2 & 32.6 & 0.134 & 243.28 \\
\hline 8 & $\mathrm{SS}$ & Square & 3 & 37.2 & 0.185 & 201.08 \\
\hline
\end{tabular}

\section{RESULTS AND ANALYSIS}

Experiments have been carried out using Taguchi's L8 Orthogonal Array (OA) experimental design which consists of eight combinations of Material of wire mesh, type of wire mesh and number of corrugated layers. It considers three process parameters to be varied in 2 discrete levels. Table 3.1 shows experimental results. Experiments have been also conducted on eight different combinations of material and types of wire mesh simultaneously. Apart from Taguchi's L8 orthogonal array (OA) experimental design, these eight combinations are chosen. Eight combinations are selected randomly, keeping the number of layers constant as 3 . Table 3.2 shows experimental results.

Table - 3.2 Experimental results of different combinations

\begin{tabular}{|c|c|c|c|c|c|c|c|c|}
\hline $\begin{array}{c}\text { Exp } \\
\text { No. }\end{array}$ & Material & \multicolumn{2}{|c|}{ orientation } & $\begin{array}{c}\text { No. of } \\
\text { layers }\end{array}$ & $\begin{array}{c}\text { Compressive } \\
\text { load KN }\end{array}$ & $\begin{array}{c}\text { Bonded Weight } \\
\mathrm{Kg}\end{array}$ & $\begin{array}{c}\text { Strength/Weight } \\
\text { Ratio } \\
\mathrm{kN} / \mathrm{kg}\end{array}$ & $\begin{array}{c}\text { Compressive } \\
\text { Stress (Mpa) }\end{array}$ \\
\hline 1 & SS-SS & R-1 & S-2 & 3 & 39.4 & 0.164 & 240.24 & 3.94 \\
\hline 2 & SS-SS & R-2 & S-1 & 3 & 37.7 & 0.147 & 256.46 & 3.77 \\
\hline 3 & SS-AL & S-2 & S-1 & 3 & 36.4 & 0.149 & 244.29 & 3.64 \\
\hline 4 & SS-Al & S-1 & S-2 & 3 & 31.0 & 0.117 & 264.95 & 3.10 \\
\hline 5 & AL-AL & R-2 & S-1 & 3 & 17.4 & 0.075 & 232.00 & 1.74 \\
\hline 6 & AL-AL & S-2 & R-1 & 3 & 20.1 & 0.081 & 248.14 & 2.01 \\
\hline 7 & SS-AL & R-2 & R-1 & 3 & 28.6 & 0.107 & 267.28 & 2.86 \\
\hline 8 & AL-SS & R-2 & R-1 & 3 & 22.5 & 0.090 & 250.00 & 2.25 \\
\hline
\end{tabular}

The strength to weight ratio obtained is entered as a response for this analysis. The results generated in terms of mean and $\mathrm{S} / \mathrm{N}$ ratio are used to draw the conclusions. The Table 3.3 indicates the $\mathrm{S} / \mathrm{N}$ ratio and mean for 8 experiments. Average values of mean for each level of each factor along with delta value and rank for each factor are given in response tables 3.4 and 3.5 for $\mathrm{S} / \mathrm{N}$ ratio and mean. 


\begin{tabular}{|c|c|c|c|c|c|c|}
\hline Sr. No & $\begin{array}{c}\text { Material of wire } \\
\text { mesh }\end{array}$ & $\begin{array}{c}\text { Types of wire } \\
\text { mesh }\end{array}$ & No of Layers & $\begin{array}{c}\text { Strength / Weight } \\
\mathbf{( k N )}\end{array}$ & S/N ratio & Mean \\
\hline 1 & Al & Round & 2 & 217.24 & 46.7388 & 217.24 \\
\hline 2 & Al & Round & 3 & 225.00 & 47.0437 & 225.00 \\
\hline 3 & Al & Square & 2 & 211.26 & 46.4963 & 211.26 \\
\hline 4 & Al & Square & 3 & 189.65 & 45.5591 & 189.65 \\
\hline 5 & SS & Round & 2 & 243.43 & 47.7275 & 243.43 \\
\hline 6 & SS & Round & 3 & 235.60 & 47.4435 & 235.60 \\
\hline 7 & SS & Square & 2 & 243.28 & 47.7221 & 243.28 \\
\hline 8 & SS & Square & 3 & 201.08 & 46.0674 & 201.08 \\
\hline
\end{tabular}

Table - 3.4 Response table for signal to noise ratio of $\mathrm{S} / \mathrm{W}$ ratio

\begin{tabular}{|c|c|c|c|c|c|}
\hline Column & Factors & Level 1 & Level 2 & Delta & Rank \\
\hline 1 & $\begin{array}{c}\text { Material of wire } \\
\text { mesh }\end{array}$ & 46.46 & 47.24 & 0.78 & 1 \\
\hline 2 & $\begin{array}{c}\text { Types of wire } \\
\text { mesh }\end{array}$ & 47.24 & 46.46 & 0.78 & 2 \\
\hline 3 & No of Layers & 47.17 & 46.53 & 0.64 & 3 \\
\hline
\end{tabular}

Table - 3.5 Response table for means of $\mathrm{S} / \mathrm{W}$ ratio

\begin{tabular}{|c|c|c|c|c|c|}
\hline Column & Factors & Level 1 & Level 2 & Delta & Rank \\
\hline 1 & Material of wire mesh & 210.8 & 230.8 & 20.1 & 1 \\
\hline 2 & Types of wire mesh & 230.8 & 211.3 & 19.0 & 2 \\
\hline 3 & No of Layers & 228.8 & 212.8 & 16.0 & 3 \\
\hline
\end{tabular}

\subsection{Main effects plot for Strength to Weight Ratio}

The main effect plot for strength to weight ratio as a response obtained is shown in Fig. 3.1. It gives comparison between effects of each level of the control factor on the response under study. The reference line drawn is showing the average mean for overall response.

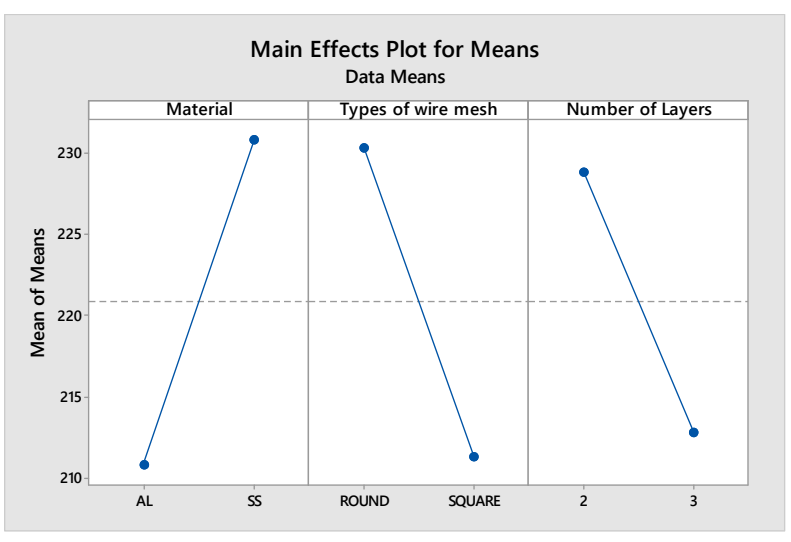


Figure 3.1 Main Effects Plot For Mean

\subsection{ANALYSIS OF VARIANCE}

ANOVA is a statistically based, objective decision making tool for detecting any differences in the average performance of groups of items tested [17]. ANOVA helps in testing the significance of all main factors and their interactions by comparing the mean square of deviations of individual factor against the experimental errors at specific confidence levels. Table 3.6 shows ANOVA for strength to weight ratio analysis. Material of Wire Mesh shows the maximum percent contribution followed by types of wire mesh and number of layers.

Table - 3.6 ANOVA for Strength to Weight Ratio

\begin{tabular}{|c|c|c|c|c|c|c|}
\hline Sr. No. & Factor & SS & DOF & MSS & F ratio & $\%$ contribution \\
\hline 1 & Material of Wire Mesh & 804.8 & 2 & 402.4 & 0.591 & 29.62 \\
\hline 2 & Types of wire Mesh & 722.0 & 2 & 361 & 0.530 & 26.15 \\
\hline 3 & Number of layers & 510.1 & 2 & 255 & 0.375 & 18.77 \\
\hline 4 & Error & 680.1 & 1 & 680 & 1 & 25.03 \\
\hline 5 & Total & 2717.0 & 7 & & & 100 \\
\hline
\end{tabular}

\subsection{CONFIRMATION OF EXPERIMENT}

The experimental confirmation test is the last step in a verifying results obtained based on Taguchi's methodology. In this step the experiments are performed for the combination of all parameters with their optimum levels and response is recorded. Then the results from the confirmation experiments are compared with the predicted results based on parameters and level tested. The confirmation experiment is a crucial step and is highly recommended by Taguchi to verify the experimental results [17]. It may be noted that if the optimal combination of parameters and their levels coincidently match with one of the experiments in the orthogonal array, then no confirmation test is required. Table 3.7 shows the confirmation experiment results.

Table - 3.7 Confirmation Experiment

\begin{tabular}{|c|c|c|c|c|c|}
\hline \multirow{2}{*}{$\begin{array}{c}\text { Exp. } \\
\text { No. }\end{array}$} & Response & $\begin{array}{c}\text { Material } \\
\text { of wire } \\
\text { mesh }\end{array}$ & $\begin{array}{c}\text { Type of wire } \\
\text { mesh }\end{array}$ & $\begin{array}{c}\text { Number of } \\
\text { corrugations }\end{array}$ & $\begin{array}{c}\text { Observed Results } \\
\text { KN/Kg }\end{array}$ \\
\hline 1 & Strength/Weight & SS & Round & 2 & 242.30 \\
\hline 2 & Strength/Weight & SS & Round & 2 & 244 \\
\hline 3 & Strength/Weight & SS & Round & 2 & 243.78 \\
\hline & \multicolumn{5}{|c|}{ Average $=243.36 \mathrm{KN} / \mathrm{Kg}$} \\
\hline
\end{tabular}

\subsection{Confidence Interval}


The estimated results are only a point estimate based on the averages of the results obtained from the experiments. While performing the confirmation experiment it is better to have a range of value than having an exact value of predicted results within which the observed values should fall with some confidence.

$$
C_{1} I_{1}= \pm \sqrt{\left(F\left(1, n_{2}\right) \times B_{+}\right) / N_{F}}
$$

Where $\mathrm{F}\left(1, \mathrm{n}_{2}\right)=161.45$

( $F$ table at a required confidence level at DOF 1 and error DOF $\mathrm{n}_{2}$ ).

$\mathrm{N}_{\mathrm{e}}=3$ (Effective number of replications)

$\mathrm{V}_{\mathrm{e}}=680.1$ (Value of error)

The $\mathrm{f}$ value is taken for $95 \%$ of confidence and the range obtained is 57.02 to 430.64 and the CI comes to be 191.31 .

Table - 3.8 Comparisons between Experimental Results and Predicted Results

\begin{tabular}{|c|c|c|c|c|c|}
\hline \multirow{2}{*}{ Sr. No. } & \multirow{2}{*}{ Response } & \multirow{2}{*}{$\begin{array}{c}\text { Predicted } \\
\text { Results }\end{array}$} & \multicolumn{2}{|c|}{$\begin{array}{c}\text { Confidence } \\
\text { Interval (C. I.) }\end{array}$} & \multirow{2}{*}{ Observed Results } \\
\cline { 4 - 5 } & & Lower & Upper & \\
\hline 1 & $\begin{array}{c}\text { Strength/weight } \\
(\mathrm{kN} / \mathrm{kg})\end{array}$ & 248.33 & 57.02 & 439.64 & 243.36 \\
\hline
\end{tabular}

\section{CONCLUSION}

Corrugated wire mesh laminates are metallic periodic open celled structures manufactured with perforated wire mesh. The potential applications for these laminates include for replacement of core material for lightweight sandwich constructions. In such applications, the laminates will mainly be subjected to compression loading. Statistically designed experiments based on Taguchi method have been performed using L8 orthogonal arrays to analyse the compressive strength of CWML along with strength/weight ratio as response variables. It characterizes the behaviour of corrugated wire mesh laminates under transverse compressive loading. After performing experimental tests on CWML samples and analysing the results using signal to noise ratio and mean approach, Taguchi's technique influences of material of wire mesh, types of wire mesh and the number of corrugated layers on these responses were established. Mean, $\mathrm{S} / \mathrm{N}$ ratio has given similar results which are verified by confirmation experiment. All the three factors effectively contributed in maximizing the compressive strength of CWML structure. Design of CWML with optimum levels of control factors results in maximum strength as well as light weight structure. The most dominating factor in CWML is material of wire mesh which affects its strength greatly as compared to other factors. The maximum load sustain by stainless steel round structure of two layers is $24.1 \mathrm{KN}$ with strength to weight ratio $243.43 \mathrm{KN} / \mathrm{Kg}$. and for the combinations of types of wire mesh and material the maximum strength to weight ratio is $267.28 \mathrm{KN} / \mathrm{Kg}$. The new parameter types of wire mesh which was considered for work was thus found most effective on the strength of CWML structure. Finally we can conclude, CWML prepared using effective levels of control factors results in lightweight structure which can be used for different lightweight applications. The bonding of different layers was done by hand. The strength of the structure can be increased by using different bonding technique. The strength of the structure is improved by bonding the CWML structure with facing skins of strong material. The wire mesh employed in this work is plane perforated wire mesh. In future corrugated model can be fabricated with different types of wire cloth such as Dutch weave wire cloth, welded wire cloth, crimped wire cloth, electroformed wire cloth, woven thermoplastic mesh, moulded mesh, interweave perforated sheet, union jack perforated sheet, oval perforated sheet, expanded metal sheets, twisted wire, and knitted mesh, it can have much possibility to be employed in biomechanics, aerospace, or ship industry. Also bonding status is also an important factor affecting the strength of corrugated wire mesh laminates structure and hence different bonding material and technique can be used and developed in future to increase the strength. Also the no. of layers can be changed and various combinations of wire mesh can be made in order to obtain highest strength to weight ratio. 


\section{REFERENCES}

[1] Choi, J., Shankar, K., and Lee, J., 2013, "Research of elasticity for a corrugated wire mesh,” Materials and Design, 52, pp. 78-91.

[2] Choi, J., Shankar, K., and Tahtali, M., 2012, "Mechanical behavior and numerical analysis of corrugated wire mesh laminates," Journal of Mechanical Science and Technology, 26 (1), pp. 73-80.

[3] Choi, J., Shankar, K., and Tahtali, M., 2013, "Numerical Investigation of Corrugated Wire Mesh Laminate," Hindawi publishing corporation, Journal of engineering.

[4] Choi, J., Shankar, K., Fien, A., and Neely, A., 2011, "Methods for manufacture of corrugated wire mesh laminates," International Journal of Aerospace and Mechanical Engineering, pp. 5-3.

[5] Rejab, M. R. M., and Cantwell, W.J., 2013, "The Mechanical Behavior of corrugated core sandwich panels," Composites: Part B 47.

[6] Sun, Y., and Gao, L., 2013, "Structural responses of all-composite improved-pyramidal truss sandwich cores," Materials and Design, 43, pp. $50-58$.

[7] Sypeck, D. J., and Wadley, H.N.G., 2002, "Cellular metal truss core sandwich structures," Advanced Engineering Materials, 4 (10), pp. 759-764.

[8] Sypeck, D. J., 2005, “Cellular truss core sandwich structures,” Applied Composite Materials, 12, pp. 229-246.

[9] Sypeck, D. J., 2005, "Wrought aluminum truss core sandwich structures," Metallurgical and Materials Transactions, B 36(1), pp. 125-131.

[10] Gibson, L. J., 2005, "Biomechanics of cellular solids," Journal of Biomechanics, 38(3), pp.377-399.

[11] Sypeck, D. J., and Wadley, H. N. G., 2001, "Multifunctional micro truss laminates: Textile synthesis and properties," Journal of Material Research, 16(3), pp. 890-897.

[12] Paika, J. K., Thayamballib A. K., and Kima, G. S., 1999, "The strength characteristics of aluminum honeycomb sandwich panels," ThinWalled Structures, 35, pp. 205-231.

[13] Kishore, R. A., Tiwari, R., Dvivedi, A., and Singh, I., 2009, "Taguchi analysis of the residual tensile strength after drilling in glass fiber reinforced epoxy composites," Journal of materials and design, (30), pp. 2186-2190.

[14] Wadley, H. N. G., Fleck, N. A., and Evans, A. G, 2003, "Fabrication and structural performance of periodic cellular metal sandwich structures," Composites Science and Technology ,63(16), pp. 2331-2343.

[15] Wadley, H. N. G., 2003, "Multifunctional periodic cellular metals," Philosophical Transactions of the Royal Society of London Series, AMathematical Physical and Engineering Sciences, 364, pp. 31-68.

[16] Tapan Bagachi, "Taguchi Methods Explained: Practical Steps to Robust Design " Prentice-Hall India Ltd., 1992.

[17] Phillip J. Ross, "Taguchi technique for quality engineering" McGraw-Hill publication.

[18] Araldite standard technical data sheet. 